\title{
A Case Study of Food Safety Good Agricultural Practices Certification with HACCP-Level Procedures for Small-Scale Produce Processors and Packers
}

\author{
Barrett Vaughan, Ph.D. \\ Associate Professor \\ College of Agriculture, Environment, and Nutrition Sciences \\ Tuskegee University \\ Henderson Hall \\ Tuskegee, Alabama U.S.A. 36088
}

\begin{abstract}
An illustrative case study observed the process undertaken by a permanent, small-scale produce-processing facility and several temporary, seasonal produce packing facilities to become certified as having food safety Good Agricultural Practices (GAP). There is a specific emphasis on how these facilities developed the required plan for HACCP (Hazardous Area Critical Control Points)-level procedures and record keeping. Information was collected from seven USDA Agricultural Marketing Service audits at the permanent processing facility and the temporary packing facilities conducted over a four-year period. The audits resulted in certification of these facilities for processing of southern peas and leafy greens and packing of watermelons at the Harmonized GAP with Global Markets Program - Intermediate Level. The case study details the changes the facilities implemented to become compliant with the requirements identified during the audits, and the development of the HACCP-level plans.
\end{abstract}

Keywords: Produce, Packing, Processing, Food Safety, Good Agricultural Practices, Certification

\section{Introduction}

As marketing opportunities expand and government regulations change, the need for fruit and vegetable farmers to become certified on Good Agricultural Practices (GAP) related to produce food safety continues to increase. Accordingly, the number of farms that obtain food safety GAP certification through third-party audits has also increased. The need for certification is market driven in many cases. Often, a commercial buyer prefers to or is required to purchase from certified farms to ensure that food is safe and to avoid lawsuits. A buyer purchasing crops from certified farms likely will require that postharvest operations, particularly processors or packers, be similarly certified as this requirement applies throughout the supply chain. An illustrative case study of the food safety GAP certification of small-scale processing and packing operations is presented here. This case documents facilities that supported the supply of produce to a commercial buyer from a group of small farms.

\section{Background}

The audit program for produce food safety is described by the U.S. Department of Agriculture (USDA) Agricultural Marketing Service (AMS) (2015) as follows: Audit Programs offers voluntary independent audits of produce suppliers throughout the production and supply chain. Good Agricultural Practices (GAP)...) audits focus on best agricultural practices to verify that fruits and vegetables are produced, packed, handled, and stored in the safest manner possible to minimize risks of microbial food safety hazards... [adhering to] U.S. Food and Drug Administration... and industry recognized food safety practices.... In January 2002, USDA AMS formally implemented the USDA... GAP... audit verification program... [and] incorporated the Produce GAPs Harmonized Food Safety Standard into its GAP...audit program in 2011. The Produce GAPs Harmonization Initiative is an all-industry effort to harmonize GAP standards.

Moreover, the United Fresh Produce Association (2015) further clarifies the goal for producers regarding this "effort": The goal... is "one audit by any credible third party, acceptable to all buyers..." [through] develop[ing] food safety [GAP] standards and audit checklists for pre- and post-harvest operations, applicable to all fresh produce commodities... on-farm operations and... regions..., and [making] them available... at no cost. 
This study involved a processing facility and several seasonal packing facilities, or packinghouses, in their efforts to obtain food safety GAP certification. Prior to the period examined, the processing facility was not required to be food safety GAP-certified although they were supplying the crops that were to be certified to a commercial buyer. Similarly, prior to the period examined, there were seasonal packing facilities that were established by these same operators in rented buildings or available structures where the crops that were to be certified were being supplied to that commercial buyer. The requirement for food safety GAP certification, which was enforced by the commercial buyer in late 2012, represented a significant change in the way that the processing facility and the seasonal packinghouses were operated thereafter.

\section{Literature Review}

Complying with the requirements for GAP for produce food safety has been an important undertaking for both farmers and farm workers. The standards for certification are high, and, necessarily, preparation and employee training activities have been adapted for a variety of audiences so that they are effective and lead to certification. In most cases, these services are obtained by the farmer from state government educational outreach resources. For example, Pennsylvania commercial produce buyers were surveyed to obtain their food safety policies; the results became the basis upon which a GAP training curriculum was developed (Tobin, Thomson, LaBorde, and Bagdonis, 2011). The grower's knowledge and confidence were increased by the on-farm workshops using the curriculum and twenty percent of participants planned to seek certification (Nayak, Tobin, Thomson, Radhakrishna, and LaBorde, 2015). Similarly, Ohio Amish farmers saw positive outcomes from the development and use of a food safety outreach program acceptable to their community (Kline, Kneen, Barrett, Kleinschmidt, and Doohan, 2012). Also, over a dozen small-scale and limited-resource farmers in Alabama were assisted in becoming GAP-certified by undertaking an assortment of activities, including large- and small-group meetings, conference calls, and individual consultations (Vaughan et al., 2014). In Canada, agricultural workers' knowledge of food safety was improved using a training video and the approach was found to be significantly effective (Mathiasen, Morley, Chapman, and Powell, 2012). Iowa growers showed improved knowledge and attitudes toward food safety from a seven-hour GAP course that combined traditional PowerPoint delivery with discussion (Shaw, Strohbehn, Naeve, Domoto, and Wilson, 2015).

\section{Methods}

The method used was an illustrative case study. Becker et al. (n.d.) defined illustrative case studies as "primarily descriptive" and "typically utiliz[ing] one or two instances of an event to show what a situation is like" ("Types of Case Studies," para. 2). The case involved a small produce-processing facility and several seasonal packing facilities; the event was the process of becoming food safety GAP-certified. Information was collected related to audit preparations, the audits themselves, post-audit briefings with the auditors, and the corrective actions needed. The audits were conducted by the Alabama Department of Agriculture and Industries, on behalf of USDA AMS, at the processing facility in December 2012, July 2013, December 2013, and July 2014, and at the various packinghouses in July 2014 and July 2016. Training and technical assistance were obtained from state government outreach resources, mainly related to the translation of the requirements into scale-specific, practicable changes necessary for certification.

\section{Description of the Permanent Processing Facility}

\subsection{Facility Specifications}

The processing facility was located in Macon County, Alabama on a privately-owned farm. The facility had an area of 2,000 square feet, equally divided into two sections with heat and air conditioning. The front of the building was used for retail; the processing area was the rear of the building. The processing area had a roll-up entrance and a standard door that led to an outdoors shipping and receiving area. The shipping and receiving area was covered by an open 5,000-square foot shelter. The water supply was from the county. The processing space floor was unfinished concrete with several floor drains and the ceiling was a drop ceiling grid with smooth, washable tiles. The walls had coved bases are the paint was washable. There was a bathroom in both the retail space and in the processing area. The processing area was equipped with a stainless steel, three-compartment sink, a hand washing sink, an ice maker, and several stainless steel tables. The outdoor shipping and receiving area had a twenty-foot-by-thirty-foot cooler, an equipment storage shed, a covered storage section for pallets and containers, and a loading dock. 


\subsection{Staffing}

Up to a half dozen mainly Spanish-speaking migrant workers staffed the facility. Most of the workers understood some English; however, their food safety training was supplied in English and Spanish.

\subsection{Crops Processed}

At the processing facility, the crops handled included purple hull peas, leafy greens — collard, kale, mustard, and turnip greens - tomatoes, peppers, squash, and onions. Most of the crops were just inspected, packed, stored, and shipped. Only a few crops were actually "processed" in the facility, that is to say, washed, cut, or shelled. In this case, the processing facility became GAP-certified for shelled purple hull peas and bundled, crated leafy greens.

\subsection{Processing Specifics}

\subsubsection{Purple Hull Peas}

Purple hull peas are a "southern pea" similar in cultivation and usage to black-eyed peas. The mature hulls vary in size from four to ten inches in length with a diameter of a half-inch, and range in color from green with purple mottling to mostly purple. They are harvested from June to October. The purple hull peas arrive at the processing facility in plastic mesh bushel bags, usually delivered in a refrigerated truck. The bags are off-loaded onto pallets and stored in the cooler on receiving. From twenty-five to thirty bushel bags of unshelled peas can be held on a pallet. The peas are removed from the cooler and loaded into a sheller for processing. The sheller efficiently removes the hull from the edible peas inside and also removes any immature peas, stems, and other debris. The sheller can shell about one bushel every 20 minutes and can be used continuously for about four to six hours before it requires cleaning and maintenance. In the processing area, only two shellers are normally used due to space, personnel, and noise and air quality concerns.

Shelled peas are removed from the sheller and run through a blower to remove debris. The peas are then inspected by hand to remove any remaining pieces of hull or debris. The inspected, shelled peas are then packed into labeled clamshells or zippered-closure, clear plastic bags, whichever is specified as the container. The product, packer, and country of origin are identified by the label which also has the item barcode. The containers are placed by tens into reusable plastic containers (RPCs), the ubiquitous black crates found in the produce sections of stores. The RPCs, or crates, are stacked on pallets and stored in the cooler at $37^{\circ} \mathrm{F}$. The stacked crates are wrapped with clear stretch wrap for shipping; it is ensured that the vehicle thermostat is set to an acceptable temperature.

\subsubsection{Leafy Greens}

Leafy greens are common, southern crops with varieties known to grow best in the cooler months. In particular, collard greens are a hearty, leafy green with large, smooth leaves and stems that can be harvested from October to March.

From November through early the next year, collard greens are processed. They arrive already bundled by a rubber band or twist-tie with the buyer's label attached and in RPCs (i.e., crates), usually by refrigerated truck. The crates are off-loaded and stacked on a pallet at the receiving area. Each crate is inspected for weight and quality. Then the crates are topped with one to two pounds of ice while they are being stacked. The crates are stacked up to five or six levels high, depending on the size of the bunches, and stored in the cooler. The stacks are wrapped with clear stretch wrap before storage or shipping.

\section{Description of the Seasonal Packing Facilities}

\subsection{Facilities Specifications}

There were three seasonal packing facilities, used over the 2014, 2015, and 2016 summer seasons to pack watermelons. These facilities were located in Autauga County, Macon County, and Dallas County, Alabama, all in the central part of the state. Much of the practices for each seasonal packinghouse were established according to the needs for that structure and site location.

\subsubsection{Autauga County, Alabama}

The Autauga County packinghouse was audited in July 2014. It was located in a rented building on a manufacturing complex. The building was formerly used as a broom factory and had 25,000 square feet. Only about three-quarters of the space was used for the packing operation as there were several idle manufacturing lines mounted in the building. The building had two main entrances, one at the front with a double ramp, and one at the rear with a loading dock and ramp. 
Both of the large entrances had roll-up doors and there were several standard doors on the sides of the buildings. The building had a small office, two bathrooms, and a break room. The water source was from the county. The ceiling in the building was high, and the light was supplied by large industrial lamps.

For the purpose of GAP certification, the lamp bulbs above the packing and storage areas were removed to prevent glass from broken bulbs from contaminating the produce. The remaining lights and sunlight proved to be sufficient for certification. There was no temperature control in the building, and large industrial fans were used to cool the building and the produce while the main entrance doors were kept open. Pest control was done by the landlord manufacturing company but numbered sticky and poison traps were installed inside and around the outside of the building, respectively.

The containers and supplies - in this case, unassembled triple-walled corrugated cardboard bins, cardstock pads, unassembled cardboard bin lids, and pallets - were stored in designated areas adjacent to the packed bin storage area. Assembled bins and lids were kept in a small, designated area near the main front entrance; assembled containers were stored on pallets.

The packed bin storage area was the largest portion of the available space in the building. The bins were usually packed at the front main door and transported by pallet jack or forklift to the rear loading dock end of the building for storage. A forklift was used to stack packed bins before or during loading of the shipping vehicle. It was ensured that the vehicle thermostat was set to about $45^{\circ} \mathrm{F}$. The watermelons were inspected upon arrival at the packinghouse. Any non-conforming, that is, diseased, underweight, leaking or busted, scarred, or grossly irregular fruit was culled or removed to a designated disposal area on the rear loading dock of the building. Often, these watermelons, if still in edible condition, were accepted by the manufacturing complex workers. Otherwise, truly bad watermelons were taken away by truck to be discarded.

\subsubsection{Macon County, Alabama}

The Macon County packinghouse was audited in July 2014. It was located in an open shed on a university farm. The shed had two sections: the front third was enclosed and used to secure farm equipment and supplies; the rear two-thirds, approximately 2,000 square feet, were open and normally used to shelter heavy equipment. The entire open shed was at ground level; the concrete pad extended beyond the shelter of the shed at the rear of the structure. A gravel road ran around the building and the front of the building was on a paved farm road. A bathroom was located in an adjacent building, and a break area was available at the front of that building. The water source was from the county. There was some lighting inside of the open shed. For the purposes of use and certification, the open area was cleared of all heavy equipment and other items and the concrete floor was pressure washed. Netting was installed from the floor to the shed completely around the perimeter, and an entrance was built at the rear with a screened, swinging door. Pest control was contracted by the university but numbered sticky and poison traps were installed inside and around the outside of the netted open shed, respectively.

The front part of the netted area, away from the door, was used for unassembled watermelon bin, pad, and lid storage. The remainder of the netted area, the majority, was used for packed bin storage. Bins were packed on the extension of the concrete pad outside of the netted area and transported into the netted area with a pallet jack. Stacking of the bins took place on the outside concrete pad with a forklift or farm machinery with forks. As there was no loading dock, the loading of the shipping vehicle was done from the outside concrete pad with the same machinery.

Watermelons were inspected upon arrival at the packinghouse. Any non-conforming fruit was culled or removed to a designated disposal area near the open shed. These watermelons, if still in edible condition, were usually taken away by the farmer who brought them to be sold to an alternate market. Otherwise, truly bad watermelons were taken away to be discarded to the livestock.

\subsubsection{Dallas County}

The Dallas County packinghouse had an educational audit in early summer 2016 and an official audit in July 2016. It was located in a purchased and remodeled building. The building was formerly used as a children's entertainment center and had 20,000 square feet. Only about one-third of the space was used for the packing operation. The remainder of the building was being remodeled or used for other purposes. The building had heating and cooling. The majority and central part of the building was an open space originally used to house games. 
The building also had several offices, two large capacity bathrooms, one small bathroom, and several large rooms. The water source was from the county. Outside of the building were three open pavilions with concrete pads, two large and one small. There was a large parking lot in front of the building.

For the purposes of certification, the light fixtures in the high ceiling of the building were replaced with high power light fixtures with break-resistant bulbs. One of the larger rooms at the rear of the building was designated for packed bin storage and was set up to be independently cooled. An access hallway to this area was created from an existing room and "cold curtains" were installed in the hallway. The building was equipped with several forklifts and pallet jacks.

As part of the remodeling, a large entrance with a roll-up door was made on a side wall of the building at the front. At this entrance, a concrete pad and loading dock was constructed. One of the larger outside open pavilions was closed in with netting and a swinging door for it to be used for pallet storage. Pest control was contracted for the building but numbered sticky and poison traps were installed inside and around the outside of the building, respectively.

The unassembled watermelon bins, pads, and lids were stored inside the building in the front of the large, central open area. The area inside nearest to the entrance with the roll-up door was designated for watermelon receiving, grading, and packing. Packed bins would be transported to the packed bin storage area by forklift or pallet jack. The forklift was used to stack and load the packed bins on the shipping vehicle through the new entrance and from the loading dock.

Watermelons were inspected upon arrival at the packinghouse. Any non-conforming fruit was culled or removed to a designated disposal area outside near the pavilions. These watermelons, if still in edible condition, were usually taken away by the farmer who brought them to be sold to an alternate market. Otherwise, truly bad watermelons were taken away to be discarded.

\subsection{Staffing}

The packinghouses were usually staffed by one or three persons who received deliveries and kept the records and invoices. These persons were university outreach personnel who had been reassigned to this seasonal duty. The Autauga County packinghouse was staffed almost seven days a week during the 2014 and 2015 seasons. The Macon County packinghouse was staffed only for deliveries and shipments during the 2014 season. The Dallas County packinghouse was staffed daily due to the ongoing remodeling during the 2016 and 2017 seasons. All staff received food safety training.

\subsection{Crops Packed}

The packinghouses were intended for the packing of watermelon. However, the Dallas County packinghouse was being remodeled to include a large cooler and processing room for the handling of other crops. The packinghouses became GAP-certified for watermelons packed in bins and stored in the facility.

\subsection{Packing Specifics - Watermelon}

The watermelons packed were seeded varieties that are preferred in the Southeastern U.S. and uniquely grown in that region. However, the size category, medium-sized at roughly around twenty pounds each, is distinctly smaller than typically grown and more preferable for the commercial market. Also, the market for these smaller, commercially-sized watermelon spans from June until September, where the market for the larger, family gathering-sized (thirty-plus pounds) exists mostly in late June and early July.

The watermelon bins and lids are shipped flat and must be assembled. The watermelon bin is triple-walled corrugated cardboard that is pre-printed with marketing such as "locally grown". The lid is corrugated cardboard. The bin, after assembled, is placed squarely on a pallet and a cardstock pad is placed inside on the bottom of the bin to separate the bottom layer of watermelon from the slats of the pallet. The empty assembled bins on pallets are stationed in the packing area.

Watermelons arrive in an open truck or trailer, are offloaded at the concrete pad or the loading dock, and taken into the packinghouse through the entrance. There they are inspected, sorted by weight, and placed into bins by size. Larger, medium-sized watermelon is placed in a bin with a total of twenty-eight. Smaller, medium-sized watermelons are placed in a bin with a total of thirty-five. Small watermelons (less than about 15 pounds) or large watermelon (greater than about thirty pounds) are set aside and returned to the farmer. 
The packed bins with a lid are transported by forklift or pallet jack to the designated storage area. For loading the shipping vehicle, the bins with lids on pallets are stacked either two or three high and loaded by forklift or other large machinery.

\section{Traceability and Labeling}

Traceability to the farm of origin, that is, the ability to trace the source of produce from the end consumer or retailer through the distributor to the supplier, is integral to food safety GAP. Because of its importance, the details of compliance in this area are documented. The strength of the traceability is the ability to identify a specific subset of shipped product that may be removed from the buyer's inventory and returned or disposed of, without the loss of a complete shipment of product.

\subsection{Purple Hull Peas}

Each pallet of bags received is tagged with a farmer identification sheet, and each RPC shipped is labeled with the crop, the case quantity and container weight, the words "Product of USA," and a lot number that identifies the farm of origin. The lot number is a seven-digit number identifying the date of processing with the three-digit day of the year, or Julian Day, the farm with a unique two-digit number, and the pallet with a two-digit number.

An example of the lot number would be "213 0101 ," which would signify that the peas were processed on day 213 , or August 1 (non-leap year), that the peas came from the farm designated as number " 01 " and were stored on pallet number "01." The label used was a commercially available two-inch by four-inch laser or inkjet printer shipping label. This lot number would uniquely identify peas that were shelled from a pallet of about twenty-five to thirty bags or approximately twenty-five to thirty-five RPCs of 10 containers each.

\subsection{Leafy Greens}

Each RPC or crate of leafy greens received is labeled at the farm with the crop, a lot number that identifies the farm of origin, and the words "Product of USA." The lot number is a seven-character code identifying the date of harvest with the three-digit day of the year, the farm with a unique two-letter code (the farmer's initials), and the field with a two-digit number. An example of the lot number would be "305 AA 01," which would signify that the leafy greens were harvested on day 305, or November 1 (non-leap year), that the leafy greens came from the farm designated as number "AA" and were grown on their field "01." The label used was a commercially available two-inch by four-inch laser or inkjet printer shipping label. This lot number would uniquely identify all of the crates of leafy greens harvested in a day from one of the farmer's fields. Typically, this would be from two hundred to four hundred twenty-five-pound crates.

\subsection{Watermelon}

Each bin of watermelon that was packed was labeled with a lot number that identifies the farm of origin and the count of the watermelon in the bin. The lot number is a four-character code identifying the farm of origin with two letters, usually the farmer's initials and the two-digit standard watermelon packing count number, either " 35 " or "28." The lot number was written directly onto the cardboard watermelon bin and on the lid at all four corners, for easy identification on in the packinghouse and on the truck. An example of the lot number would be "BB 28" which would signify that the watermelon came from the farmer whose initials were "BB" and the box had a count of twenty-eight of the larger, medium-sized watermelons. A large print marker, which was cheap and readily available at many stores, was typically used. Printed labels were considered, but there were no reliable means to print them on-site at the packinghouse and labeling by hand (at that time) was more expedient. This lot number would uniquely identify all of the bins of watermelon harvested and shipped in the same vehicle under the same bill of lading; the maximum would be from fifty-eight to sixty seven hundred-pound bins.

\section{HACCP-level requirements}

\subsection{HACCP definition}

HACCP is an acronym for "Hazard Analysis Critical Control Point." According to the Food and Drug Administration (FDA): HACCP is a management system in which food safety is addressed through the analysis and control of biological, chemical, and physical hazards from raw material production, procurement and handling, to manufacturing, distribution and consumption of the finished product. (FDA, 2018)

This "management system" was also adopted by the USDA Food Safety Inspection Service (FSIS) for their food safety programs. 
According to the FSIS Inspection Methods Training: The National Advisory Committee on Microbiological Criteria for Food (NACMCF) working group created guidelines and redefined the seven basic principles of HACCP as an effective and rational means of assuring food safety from harvest to consumption... The seven principles of HACCP, which encompass a systematic approach to the identification, prevention, and control of food safety hazards include:

1. Conduct a Hazard Analysis

2. Determine Critical Control Points

3. Establish Critical Limits

4. Establish Monitoring Procedures

5. Establish Corrective Actions

6. Establish Recordkeeping and Documentation Procedures

7. Establish Verification Procedures (FSIS, 2016)

\subsection{HACCP requirement in produce food safety GAP}

The requirements for the Global Markets Program - Intermediate Level certification involved addressing the specific handling of crops, required a Hazard Analysis Critical Control Points (HACCP) plan or a written study of work (or process) flow addressing the potential for contamination, and required a plan for food defense. Under the requirements from 2014, there were two questions on the audit checklist that pertained to risk assessment and HACCP-level planning for packinghouses, questions 4.1.2 and 4.1.3:

\subsubsection{Operation has performed and documented a risk assessment of the packinghouse.}

4.1.3 If the risk assessment shows the need for a critical control point(s) in the packinghouse, a documented HACCP plan or additional procedures addressing monitoring of control points and disposition of non-conforming products must be in place. The HACCP plan or additional policies must be documented and implemented. In this case, the facility management did not access any resources to help them to establish an actual HACCP plan. Instead, they opted to establish the "additional procedures addressing monitoring of control points and disposition of non-conforming products" with a risk assessment.

\section{Results}

\subsection{Food Safety GAP Certification}

There were seven audits that took place under the case study period from December 2012 to July 2016; all the audits were successful. Therefore, the processing facility was GAP-certified for processing southern peas and leafy greens during the 2013, 2014, and 2015 seasons, and the packinghouses were GAP-certified for the packing of watermelons during the 2014, 2015, and 2016 seasons. These certifications were at the USDA AMS Produce Harmonized GAP with Global Markets Program - Intermediate Level. This represents the most rigorous audit scheme offered by the USDA. The audit was extensive and addressed areas such as worker training, water quality, pest control, and facility maintenance.

The preparation for the audit involved the facility management making numerous changes to typical practices based on requirements in the audit scheme. The facility management, with technical assistance from state government outreach resources, developed a complete and inclusive food safety plan that outlined procedures for making, reviewing, and evaluating the required changes. The changes that were required pertained to the two main areas of personnel and record keeping and of facilities, equipment, and handling (Tables 1 and 2). Additional changes were needed to meet the supplemental requirements for the Global Markets Program Intermediate Level (Table 3). The expenses involved with obtaining food safety GAP certification, aside from the audit $(\$ 1,000-\$ 2,000)$, were generally the purchase or rental of new containers and supplies, labeling, transportation and storage, equipment upgrades (i.e., to stainless steel), handling, water testing, record keeping, and management. 
Table 1. Produce Harmonized GAP Requirements - Personnel and Record Keeping

\begin{tabular}{|l|l|l|}
\hline Area of requirements & $\begin{array}{l}\text { Typical Practices } \\
\text { Before Certification }\end{array}$ & $\begin{array}{l}\text { Changes Needed for Certification per the Food } \\
\text { Safety Plan }\end{array}$ \\
\hline $\begin{array}{l}\text { Management } \\
\text { Responsibility }\end{array}$ & $\begin{array}{l}\text { Management personnel shared } \\
\text { responsibility }\end{array}$ & Personnel dedicated for food safety management \\
\hline $\begin{array}{l}\text { Food Safety Plan or Risk } \\
\text { Assessment }\end{array}$ & $\begin{array}{l}\text { No formal food safety plan established, } \\
\text { general cleanliness }\end{array}$ & Food safety plan developed and reviewed \\
\hline Raw Material Sourcing & $\begin{array}{l}\text { Food safety certification not required for } \\
\text { supplying farms }\end{array}$ & $\begin{array}{l}\text { Food safety certification required for farms } \\
\text { supplying produce to buyers that require } \\
\text { certification }\end{array}$ \\
\hline $\begin{array}{l}\text { Documentation \& } \\
\text { Recordkeeping }\end{array}$ & $\begin{array}{l}\text { Record keeping informal and loosely } \\
\text { organized }\end{array}$ & $\begin{array}{l}\text { Record keeping on all required aspects of } \\
\text { processing operation }\end{array}$ \\
\hline $\begin{array}{l}\text { Worker Education \& } \\
\text { Training }\end{array}$ & Training informal and as needed & $\begin{array}{l}\text { Training formalized, uniform with industry, and } \\
\text { required at hire and annually }\end{array}$ \\
\hline Traceability & $\begin{array}{l}\text { Mostly direct-to-consumer sales; some } \\
\text { records kept for commercial sales }\end{array}$ & $\begin{array}{l}\text { Developed lot numbers, labeling for containers and } \\
\text { pallet, records for produce in and out }\end{array}$ \\
\hline Recall Program & Recall possible for most recent sales & $\begin{array}{l}\text { Recall records, team, and procedures established } \\
\text { and tested }\end{array}$ \\
\hline Corrective Actions & $\begin{array}{l}\text { Actions taken as needed; general } \\
\text { standard }\end{array}$ & $\begin{array}{l}\text { Actions required and recorded; based on food } \\
\text { safety standards }\end{array}$ \\
\hline Self Audits & Review of practices as needed & Annual review of all food safety practices \\
\hline
\end{tabular}

Table 2. Produce Harmonized GAP Requirements- Facilities, Equipment, and Handling

\begin{tabular}{|c|c|c|}
\hline Area of requirements & $\begin{array}{l}\text { Typical Practices } \\
\text { Before Certification }\end{array}$ & $\begin{array}{l}\text { Changes Needed for Certification per the Food Safety } \\
\text { Plan }\end{array}$ \\
\hline $\begin{array}{l}\text { Agricultural Chemicals/Plant Protection } \\
\text { Products }\end{array}$ & Chemicals stored where convenient & All chemicals labeled with dedicated storages areas \\
\hline Water/Ice & Municipal water used, a tested source & Water tests recorded; facility water system documented \\
\hline Containers, Bins & Containers stored where convenient & $\begin{array}{l}\text { Containers stored to reduce risk of contamination and } \\
\text { labeled }\end{array}$ \\
\hline Facility, Equipment, Tools & $\begin{array}{l}\text { Facility, equipment, and tools used with } \\
\text { general cleanliness }\end{array}$ & $\begin{array}{l}\text { Facility, equipment, and tools assessed for food safety } \\
\text { risk and actions taken and recorded }\end{array}$ \\
\hline Storage & Storage utilized with general cleanliness & $\begin{array}{l}\text { Storage assessed for food safety risk and actions taken } \\
\text { and recorded }\end{array}$ \\
\hline Waste Material & Wastes discarded as needed & Processing wastes and other wastes managed separately \\
\hline Outside Grounds & Cleaned as needed & Kept cleaned and mowed; trash bins maintained \\
\hline Glass Control & Lights in building were covered & $\begin{array}{l}\text { Lights inside and outside of building and vehicles are } \\
\text { checked }\end{array}$ \\
\hline Leaks/Lubricants & $\begin{array}{l}\text { Problems addressed as needed; no formal } \\
\text { plan }\end{array}$ & Records kept; spill procedures defined \\
\hline Equipment and Utensil Construction & $\begin{array}{l}\text { Wood, steel, aluminum, stainless steel, } \\
\text { and plastic used }\end{array}$ & Stainless steel equipment and tables were purchased \\
\hline Temporary Repairs & $\begin{array}{l}\text { Repairs completed as needed by usual } \\
\text { standards }\end{array}$ & Repairs completed and recorded by food safety standards \\
\hline $\begin{array}{l}\text { Worker Health/ Hygiene and Toilet/ Hand } \\
\text { washing Facilities }\end{array}$ & $\begin{array}{l}\text { Bathrooms available and cleaned } \\
\text { regularly }\end{array}$ & $\begin{array}{l}\text { Records kept of cleaning and stocking of required } \\
\text { supplies }\end{array}$ \\
\hline Temperature Control & $\begin{array}{l}\text { Temperature of cooler checked when } \\
\text { entered }\end{array}$ & $\begin{array}{l}\text { Temperature of cooler checked, calibrated, and } \\
\text { maintenance recorded }\end{array}$ \\
\hline Packing and Handling & $\begin{array}{l}\text { Packing and handling with general } \\
\text { cleanliness }\end{array}$ & Workers trained on food safe packaging and handling \\
\hline Pest and Animal Control & Pest control as needed & Professional pest and animal control at least monthly \\
\hline Sampling / Testing & $\begin{array}{l}\text { Water sampling and testing not required, } \\
\text { municipal source }\end{array}$ & Sampling procedures documented in plan \\
\hline Packinghouse - Water Use on Produce & Water from municipal source, not tested & Water tests recorded for ice maker source, municipal \\
\hline Transportation - Temperature Control & $\begin{array}{l}\text { Refrigerated vehicle typically used, } \\
\text { temperature checked }\end{array}$ & Temperature checked and recorded for shipments \\
\hline $\begin{array}{l}\text { Transportation - Equipment Sanitation and } \\
\text { Maintenance }\end{array}$ & Vehicles checked for cleanliness & Records kept of vehicle condition \\
\hline
\end{tabular}




\section{Table 3. Produce Harmonized GAP Global Markets Program - Intermediate Level Requirements}

\begin{tabular}{|c|c|c|}
\hline Area of requirements & $\begin{array}{l}\text { Typical Practices } \\
\text { Before Certification }\end{array}$ & $\begin{array}{l}\text { Changes Needed for Certification per the } \\
\text { Food Safety Plan }\end{array}$ \\
\hline \multicolumn{3}{|c|}{ Food Safety Plan and Documentation } \\
\hline $\begin{array}{l}\text { Customer's Food Safety } \\
\text { Specifications }\end{array}$ & $\begin{array}{l}\text { Food safety not required outside } \\
\text { of general cleanliness }\end{array}$ & $\begin{array}{l}\text { Processing under food safety specification } \\
\text { required by customer }\end{array}$ \\
\hline Risk Assessment & $\begin{array}{l}\text { Risks assessed by general } \\
\text { cleanliness }\end{array}$ & $\begin{array}{l}\text { Potential risks assessed according to process } \\
\text { and food safety, measures to be taken in plan }\end{array}$ \\
\hline $\begin{array}{l}\text { HACCP Plan or Additional } \\
\text { Monitoring Procedures }\end{array}$ & $\begin{array}{l}\text { General cleanliness and attention } \\
\text { to process steps }\end{array}$ & $\begin{array}{l}\text { Additional monitoring procedures in place, } \\
\text { similar to HACCP }\end{array}$ \\
\hline $\begin{array}{l}\text { Program for Non-Conforming } \\
\text { Product }\end{array}$ & $\begin{array}{l}\text { Non-conforming products } \\
\text { typically discarded }\end{array}$ & $\begin{array}{l}\text { Actions regarding non-conforming products in } \\
\text { plan, recorded }\end{array}$ \\
\hline Corrective Actions Procedures & $\begin{array}{l}\text { Addressed as needed by general } \\
\text { standards }\end{array}$ & Required, recorded by food safety standards \\
\hline $\begin{array}{l}\text { Non-Conformance and Complaint } \\
\text { Recordkeeping }\end{array}$ & $\begin{array}{l}\text { Addressed as needed by general } \\
\text { standards }\end{array}$ & $\begin{array}{l}\text { Actions required and recorded by food safety } \\
\text { standards }\end{array}$ \\
\hline Food Safety Incident Procedures & Addressed as needed & $\begin{array}{l}\text { Practices in place to address incidents, } \\
\text { recorded }\end{array}$ \\
\hline Approved Supplier Program & $\begin{array}{l}\text { Purchases made where } \\
\text { convenient }\end{array}$ & Suppliers recorded and information verified \\
\hline $\begin{array}{l}\text { Metal Detection Equipment, if } \\
\text { utilized }\end{array}$ & Not utilized & Not required, may utilize in future \\
\hline \multicolumn{3}{|l|}{ Food Defense } \\
\hline Threat Assessment & $\begin{array}{l}\text { General access control with } \\
\text { signage }\end{array}$ & $\begin{array}{l}\text { Potential threats assessed with food defense } \\
\text { plan }\end{array}$ \\
\hline Access Control & Primarily signage & $\begin{array}{l}\text { Signage, entry and exit recording, } \\
\text { enforcement access restrictions }\end{array}$ \\
\hline Sabotage Evaluation Measures & Determined as needed & $\begin{array}{l}\text { Plan to detect sabotage, measures determined } \\
\text { when detected, actions recorded }\end{array}$ \\
\hline
\end{tabular}

The audits for the processing facility and the packinghouses were successful, yet there were a few corrective actions needed. For the processing facility, these corrective actions needed concerned the water system, container storage, and records of pest control. For the packinghouses, the corrective actions needed involved the approved supplier list. Otherwise, the processing and packing operations were in compliance in key areas such as worker training, water quality, and traceability, which is a concept central to food safety GAP.

\subsection{HACCP-Level Planning - Risk Assessment, Process Flow, and Additional Procedures}

The development of the risk assessment involved a complete examination of the process flow for processing and packing the crops and then identifying the steps, or points, where the produce could potentially become contaminated. The processing facility and packinghouse management accomplished this task with technical assistance from state government outreach resources. Risk assessments were devised for purple hull peas for the processing facility and for watermelon for the packinghouses. For the purple hull peas, there were seven processes identified in the process flow: receiving; storage - cooling of raw product (if necessary); pre-processing; processing - shelling; post-processing - packing; storage - cooling of the finished product; and, loading/shipping. Each of these processes entailed several steps (Table 4). For these processes, there were several potential hazards identified for which a measure or monitoring was defined, and a corrective action was determined (Tables 5, 6, 7, 8,9 , and 10). 


\section{Table 4. Process Flow - Purple Hull Peas}

\begin{tabular}{|c|c|}
\hline Process & Steps \\
\hline Receiving & $\begin{array}{l}\text { Unload bags and weigh } \\
\text { Check for quality, size, shape } \\
\text { Inspection for damage } \\
\text { Check for spills on bags or peas } \\
\text { Check for excess wetness or dryness } \\
\text { Check for excess heat }\end{array}$ \\
\hline $\begin{array}{l}\text { Storage - Cooling (Raw Product, } \\
\text { if necessary) }\end{array}$ & $\begin{array}{l}\text { Check pallet and jack for cleanliness } \\
\text { Check cooler temperature } \\
\text { Check cooler for cleanliness } \\
\text { Check for condensation } \\
\text { Place pallet in cooler }\end{array}$ \\
\hline Pre-processing & $\begin{array}{l}\text { Clean tables and containers } \\
\text { Move product from cooler into facility } \\
\text { Check or clean sheller }\end{array}$ \\
\hline Processing - Shelling & $\begin{array}{l}\text { Sheller loaded with peas from bags } \\
\text { Shelled peas transferred from sheller tray to containers } \\
\text { Hulls and debris transferred to waste containers }\end{array}$ \\
\hline Post-processing - Packing & $\begin{array}{l}\text { Clamshells loaded from containers } \\
\text { Sample clamshells weighed } \\
\text { Clamshells loaded into crates } \\
\text { Crates loaded onto pallets } \\
\text { Pallets transferred to cooler }\end{array}$ \\
\hline $\begin{array}{l}\text { Storage }- \text { Cooling } \quad \text { (Finished } \\
\text { Product) }\end{array}$ & (see above, Storage - Cooling) \\
\hline Loading/Shipping & $\begin{array}{l}\text { Truck checked for temperature, cleanliness, and glass/plastic breakage } \\
\text { Pallets transferred from cooler to truck }\end{array}$ \\
\hline
\end{tabular}

Table 5. Additional Procedures - Receiving - Purple Hull Peas

\begin{tabular}{|l|l|l|}
\hline Potential Hazards & Measures / Monitoring & Corrective Actions \\
\hline Peas or bags contact or spill onto floor & Use of pallets for unloading & $\begin{array}{l}\text { Product in contact with floor is discarded. } \\
\text { Loss recorded and reported. }\end{array}$ \\
\hline Peas damaged/biological contamination & Visual check & $\begin{array}{l}\text { Damaged peas discarded. Loss recorded } \\
\text { and reported }\end{array}$ \\
\hline $\begin{array}{l}\text { Spill of blood or other } \\
\text { contaminant/chemical on bag or peas }\end{array}$ & $\begin{array}{l}\text { Visual or physical check during } \\
\text { unloading }\end{array}$ & $\begin{array}{l}\text { Effected peas discarded. Bags held. Loss } \\
\text { recorded and reported }\end{array}$ \\
\hline Excess wetness of peas & $\begin{array}{l}\text { Visual and physical check for } \\
\text { mold/fungus growth }\end{array}$ & $\begin{array}{l}\text { If moldy, discard. Loss recorded and } \\
\text { reported. If not moldy, fan-dried. }\end{array}$ \\
\hline Excess dryness of peas & Visual and physical check & $\begin{array}{l}\text { Peas discarded. Loss recorded and } \\
\text { reported }\end{array}$ \\
\hline
\end{tabular}

Table 6. Additional Procedures - Storage - Cooling - Purple Hull Peas

\begin{tabular}{|l|l|l|}
\hline Potential Hazards & Measures / Monitoring & Corrective Actions \\
\hline Peas or bags contact or spill onto floor & $\begin{array}{l}\text { Use of pallets for unloading; care } \\
\text { with placing in cooler }\end{array}$ & $\begin{array}{l}\text { Product in contact with floor is discarded. Loss recorded } \\
\text { and reported. }\end{array}$ \\
\hline Peas damaged/biological contamination & Visual check & Damaged peas discarded. Loss recorded and reported \\
\hline $\begin{array}{l}\text { Spill of blood or other } \\
\text { contaminant/chemical on bag or peas }\end{array}$ & $\begin{array}{l}\text { Visual or physical check during } \\
\text { storing }\end{array}$ & $\begin{array}{l}\text { Effected peas discarded. Bags held. Loss recorded and } \\
\text { reported }\end{array}$ \\
\hline Pallet or jack not clean. Cooler not clean. & Visual check & Discard pallet; use alternate. Clean jack or cooler. \\
\hline $\begin{array}{l}\text { Cooler temperature not in range (cooler } \\
\text { operational) }\end{array}$ & $\begin{array}{l}\text { Check thermometer in cooler to } \\
\text { confirm in range }\end{array}$ & $\begin{array}{l}\text { Set cooler to compensate. If stored product effected } \\
\text { check to see if needed to be discarded. }\end{array}$ \\
\hline $\begin{array}{l}\text { Cooler temperature not in range (cooler } \\
\text { not operational) }\end{array}$ & $\begin{array}{l}\text { Check thermometer in cooler; } \\
\text { airflow of cooler fans. }\end{array}$ & $\begin{array}{l}\text { Effected product discarded; alternate cooling facility } \\
\text { secured; operation stopped until secured or cooler } \\
\text { repaired }\end{array}$ \\
\hline Excessive condensate in cooler & $\begin{array}{l}\text { Visual check of condensate on } \\
\text { floor }\end{array}$ & Condensate swept to drain \\
\hline
\end{tabular}


Table 7. Additional Procedures - Pre-processing - Purple Hull Peas

\begin{tabular}{|l|l|l|}
\hline Potential Hazards & Measures / Monitoring & Corrective Actions \\
\hline $\begin{array}{l}\text { Peas or bags contact or spill onto } \\
\text { floor }\end{array}$ & Care with pallet when moving & $\begin{array}{l}\text { Product in contact with floor is } \\
\text { discarded. Loss recorded and } \\
\text { reported. }\end{array}$ \\
\hline $\begin{array}{l}\text { Peas damaged/biological } \\
\text { contamination }\end{array}$ & Visual check & $\begin{array}{l}\text { Damaged peas discarded. Loss } \\
\text { recorded and reported }\end{array}$ \\
\hline $\begin{array}{l}\text { Spill of blood or other } \\
\text { contaminant/chemical on bag, } \\
\text { peas, tables, or floor }\end{array}$ & $\begin{array}{l}\text { Visual or physical check during } \\
\text { transfer }\end{array}$ & $\begin{array}{l}\text { Effected peas discarded. Bags held. } \\
\text { Loss recorded and reported. Tables, } \\
\text { floor cleaned and disinfected }\end{array}$ \\
\hline Tables not clean & Visual check & Tables cleaned and disinfected \\
\hline Sheller not clean & Visual check & Sheller cleaned and disinfected \\
\hline
\end{tabular}

Table 8. Additional Procedures - Processing - Shelling - Purple Hull Peas

\begin{tabular}{|l|l|l|}
\hline Potential Hazards & Measures / Monitoring & Corrective Actions \\
\hline Peas contact or spill onto floor & $\begin{array}{l}\text { Care with transfer of peas from } \\
\text { bags to sheller and sheller to } \\
\text { container }\end{array}$ & $\begin{array}{l}\text { Product in contact with floor is discarded. Loss } \\
\text { recorded and reported. }\end{array}$ \\
\hline $\begin{array}{l}\text { Peas damaged/biological } \\
\text { contamination }\end{array}$ & Visual check & $\begin{array}{l}\text { Damaged peas discarded. Loss recorded and } \\
\text { reported }\end{array}$ \\
\hline $\begin{array}{l}\text { Spill of blood or other } \\
\text { contaminant/chemical on bag or } \\
\text { peas }\end{array}$ & $\begin{array}{l}\text { Visual or physical check during } \\
\text { loading of sheller }\end{array}$ & $\begin{array}{l}\text { Effected peas discarded. Bags held. Loss } \\
\text { recorded and reported }\end{array}$ \\
\hline Spill of lubricant & Visual check & $\begin{array}{l}\text { Only food grade lubricant used; effected peas } \\
\text { discarded. Loss recorded and reported }\end{array}$ \\
\hline $\begin{array}{l}\text { Mixing of hulls or debris and } \\
\text { shelled peas }\end{array}$ & $\begin{array}{l}\text { Visual check; care with } \\
\text { discarding of wastes }\end{array}$ & $\begin{array}{l}\text { Sheller discards hulls and debris at different part } \\
\text { of machine. Containers dedicated for peas; waste } \\
\text { containers for hulls and debris }\end{array}$ \\
\hline $\begin{array}{l}\text { Contamination found during } \\
\text { shelling process }\end{array}$ & $\begin{array}{l}\text { Visual inspection at loading and } \\
\text { unloading of sheller }\end{array}$ & $\begin{array}{l}\text { Sheller shut down. Product held or discarded; } \\
\text { incident reported. Sheller cleaned and disinfected. }\end{array}$ \\
\hline $\begin{array}{l}\text { Contamination found in multiple } \\
\text { bags }\end{array}$ & $\begin{array}{l}\text { Visual inspection at transfer of } \\
\text { bag and/or loading and unloading } \\
\text { of sheller. }\end{array}$ & $\begin{array}{l}\text { No more bags shelled from effected shipment. } \\
\text { Order cancelled; incident reported. }\end{array}$ \\
\hline
\end{tabular}

Table 9. Additional Procedures - Post-processing - Purple Hull Peas

\begin{tabular}{|l|l|l|}
\hline Potential Hazards & Measures / Monitoring & Corrective Actions \\
\hline Peas contact or spill onto floor & $\begin{array}{l}\text { Care when transferring from sheller to } \\
\text { tables; care with packing clamshells } \\
\text { and loading crates and transfer to cooler }\end{array}$ & $\begin{array}{l}\text { Product in contact with floor is discarded. Loss } \\
\text { recorded and reported. }\end{array}$ \\
\hline $\begin{array}{l}\text { Peas damaged/biological } \\
\text { contamination }\end{array}$ & Visual check & $\begin{array}{l}\text { Damaged peas discarded. Loss recorded and } \\
\text { reported }\end{array}$ \\
\hline $\begin{array}{l}\text { Spill of blood or other } \\
\text { contaminant/chemical peas, tables, } \\
\text { containers, crates or floor }\end{array}$ & $\begin{array}{l}\text { Visual or physical check during transfer } \\
\text { and packing }\end{array}$ & $\begin{array}{l}\text { Effected peas discarded. Loss recorded and reported. } \\
\text { Tables, containers, floor cleaned and disinfected. } \\
\text { Clamshells discarded. Crates cleaned, tagged, and } \\
\text { held for recycling }\end{array}$ \\
\hline Peas handled with unclean hands & Visual check or monitoring of activities & $\begin{array}{l}\text { Effected peas discarded, all batches; worker cited for } \\
\text { violation and/or dismissed }\end{array}$ \\
\hline Worker observed with illness & Visual check or monitoring for illness & $\begin{array}{l}\text { Effected peas discarded, all batches; worker cited for } \\
\text { violation and/or dismissed }\end{array}$ \\
\hline Tables or equipment not clean & Visual check & Tables or equipment cleaned and disinfected \\
\hline Clamshell not clean & Visual check & Clamshell discarded \\
\hline Crate not clean & Visual or physical check & Crate cleaned, tagged, and held for recycling \\
\hline
\end{tabular}


Table 10. Additional Procedures - Loading/Shipping - Purple Hull Peas

\begin{tabular}{|c|c|c|}
\hline Potential Hazards & Measures / Monitoring & Corrective Actions \\
\hline Peas or bags contact or spill onto floor & Care with of pallets for loading & $\begin{array}{l}\text { Product in contact with floor is } \\
\text { discarded. Loss recorded and } \\
\text { reported. }\end{array}$ \\
\hline Peas damaged/biological contamination & Visual check & $\begin{array}{l}\text { Damaged peas discarded. Loss } \\
\text { recorded and reported }\end{array}$ \\
\hline $\begin{array}{l}\text { Spill of blood or other } \\
\text { contaminant/chemical on bag or peas }\end{array}$ & $\begin{array}{l}\text { Visual or physical check during } \\
\text { loading }\end{array}$ & $\begin{array}{l}\text { Effected peas discarded. Bags held. } \\
\text { Loss recorded and reported }\end{array}$ \\
\hline Temperature of truck not within range & $\begin{array}{l}\text { Check temperature on truck; } \\
\text { check operation of refrigeration } \\
\text { unit }\end{array}$ & $\begin{array}{l}\text { Halt loading until temperature in } \\
\text { range. Cancel shipment if range is } \\
\text { not able to be met }\end{array}$ \\
\hline Truck not clean & Visual inspection & $\begin{array}{l}\text { Request that truck be cleaned; Halt } \\
\text { loading until clean. }\end{array}$ \\
\hline $\begin{array}{l}\text { Truck has bad odor such as from shipping } \\
\text { meat }\end{array}$ & Inspection of truck & Cancel loading; request another truck \\
\hline $\begin{array}{l}\text { Truck has broken glass or plastic } \\
\text { components inside or outside }\end{array}$ & Inspection of truck & Cancel loading; request another truck \\
\hline
\end{tabular}

For the watermelon, there were three processes identified in the process flow: receiving; packing/storage; and, loading/shipping. Each of these processes entailed several steps (Table 11). For these processes, there were several potential hazards identified for which a measure or monitoring was defined, and a corrective action was determined (Tables 12, 13, and 14).

Table 11. Process Flow - Watermelons

\begin{tabular}{|l|l|}
\hline Process & Steps \\
\hline Receiving & Check for quality, size, shape \\
& Inspection for damage or disease \\
& Check for spills on watermelons \\
& Unload watermelon \\
\hline Packing / Storage & Check pallet and jack for cleanliness \\
& Check packing and storage areas for cleanliness \\
& Place pallets in packing area \\
& Clean tables and inspect bins \\
& Sort and pack watermelon in bins on pallets \\
& Culls and debris transferred to waste containers \\
& Bins on pallets transferred to storage area \\
& Pallets stacked, when necessary \\
\hline Loading / Shipping & Truck checked for temperature, cleanliness, and glass/plastic breakage \\
& Pallets transferred from cooler to truck \\
\hline
\end{tabular}

Table 12. Additional Procedures - Receiving - Watermelons

\begin{tabular}{|l|l|l|}
\hline Potential Hazards & Measures / Monitoring & Corrective Actions \\
\hline $\begin{array}{l}\text { Watermelons contact or spill onto } \\
\text { floor }\end{array}$ & Care with unloading & $\begin{array}{l}\text { Product in contact with floor is discarded. } \\
\text { Loss recorded and reported. }\end{array}$ \\
\hline $\begin{array}{l}\text { Watermelons damaged/biological } \\
\text { contamination }\end{array}$ & Visual check & $\begin{array}{l}\text { Damaged/contaminated watermelons } \\
\text { discarded. Loss recorded and reported }\end{array}$ \\
\hline Watermelons diseased & Visual check & $\begin{array}{l}\text { Diseased watermelons discarded. Loss } \\
\text { recorded and reported }\end{array}$ \\
\hline $\begin{array}{l}\text { Spill of blood or other } \\
\text { contaminant/chemical on } \\
\text { watermelons }\end{array}$ & $\begin{array}{l}\text { Visual or physical check } \\
\text { during unloading }\end{array}$ & $\begin{array}{l}\text { Effected watermelons discarded. Loss } \\
\text { recorded and reported }\end{array}$ \\
\hline
\end{tabular}




\section{Table 13. Additional Procedures - Packing / Storage - Watermelons}

\begin{tabular}{|l|l|l|}
\hline Potential Hazards & Measures / Monitoring & Corrective Actions \\
\hline $\begin{array}{l}\text { Watermelons contact or spill onto } \\
\text { floor }\end{array}$ & Care with pallets for unloading & $\begin{array}{l}\text { Product in contact with floor is } \\
\text { discarded. Loss recorded and } \\
\text { reported. }\end{array}$ \\
\hline $\begin{array}{l}\text { Watermelons damaged/biological } \\
\text { contamination }\end{array}$ & Visual check & $\begin{array}{l}\text { Damaged/contaminated watermelons } \\
\text { discarded. Loss recorded and } \\
\text { reported }\end{array}$ \\
\hline $\begin{array}{l}\text { Watermelons damaged/biological } \\
\text { contamination }\end{array}$ & Visual check & $\begin{array}{l}\text { Diseased watermelons discarded. } \\
\text { Loss recorded and reported }\end{array}$ \\
\hline $\begin{array}{l}\text { Spill of blood or other } \\
\text { contaminant/chemical on } \\
\text { watermelons }\end{array}$ & $\begin{array}{l}\text { Visual or physical check during } \\
\text { storing }\end{array}$ & $\begin{array}{l}\text { Effected watermelons and bin } \\
\text { discarded. Loss recorded and } \\
\text { reported }\end{array}$ \\
\hline Pallet or jack not clean. & Visual check & $\begin{array}{l}\text { Discard pallet; use alternate. Clean } \\
\text { jack. }\end{array}$ \\
\hline Packing or storage area not clean & Visual check of floor & Sweep and/or mop and allow to dry \\
\hline Tables not clean & Visual check & Tables cleaned and disinfected \\
\hline Bin not clean & Visual check & Bin discarded and replaced \\
\hline $\begin{array}{l}\text { Watermelons handled with } \\
\text { unclean hands }\end{array}$ & $\begin{array}{l}\text { Visual check or monitoring of } \\
\text { activities }\end{array}$ & $\begin{array}{l}\text { Effected watermelons discarded; } \\
\text { worker cited for violation and/or } \\
\text { dismissed }\end{array}$ \\
\hline Worker observed with illness & $\begin{array}{l}\text { Visual check or monitoring for } \\
\text { illness }\end{array}$ & $\begin{array}{l}\text { Effected watermelons discarded; } \\
\text { worker cited for violation and/or } \\
\text { dismissed }\end{array}$ \\
\hline Spill of lubricant or fork lift fluids & Visual check & $\begin{array}{l}\text { Spill cleaned. Effected watermelons } \\
\text { and/or bins discarded. Loss recorded } \\
\text { and reported }\end{array}$ \\
\hline
\end{tabular}

Table 14. Additional Procedures - Loading/Shipping - Watermelons

\begin{tabular}{|l|l|l|}
\hline Potential Hazards & Measures / Monitoring & Corrective Actions \\
\hline $\begin{array}{l}\text { Watermelons contact or spill onto } \\
\text { floor }\end{array}$ & Care with of pallets for loading & $\begin{array}{l}\text { Product in contact with floor is } \\
\text { discarded. Loss recorded and } \\
\text { reported. }\end{array}$ \\
\hline $\begin{array}{l}\text { Watermelons damaged/biological } \\
\text { contamination/diseased }\end{array}$ & Visual check & $\begin{array}{l}\text { Damaged/contaminated/ diseased } \\
\text { watermelons discarded. Loss } \\
\text { recorded and reported }\end{array}$ \\
\hline $\begin{array}{l}\text { Spill of blood or other } \\
\text { contaminant/chemical on } \\
\text { watermelons and/or bins }\end{array}$ & $\begin{array}{l}\text { Visual or physical check during } \\
\text { loading }\end{array}$ & $\begin{array}{l}\text { Effected watermelons and bin } \\
\text { discarded. Loss recorded and } \\
\text { reported }\end{array}$ \\
\hline $\begin{array}{l}\text { Temperature of truck not within } \\
\text { range }\end{array}$ & $\begin{array}{l}\text { Check temperature on truck; check } \\
\text { operation of refrigeration unit } \\
\text { Halt loading until temperature in } \\
\text { not able to be met }\end{array}$ \\
\hline $\begin{array}{l}\text { Truck not clean } \\
\text { nruck has bad odor such as from } \\
\text { shipping meat }\end{array}$ & Visual inspection & $\begin{array}{l}\text { Request that truck be cleaned; Halt } \\
\text { loading until clean. }\end{array}$ \\
\hline $\begin{array}{l}\text { Truck has broken glass or plastic } \\
\text { components inside or outside }\end{array}$ & Inspection of truck & Cancel loading; request another truck \\
\hline
\end{tabular}

The documentation of the process flow and the establishment of the additional procedures were sufficient to satisfy the requirements for a risk assessment and HACCP-level plan as specified under the Global Markets Program - Intermediate Level.

\section{Conclusion}

The management at the small-scale processing facility and the packinghouses made significant changes before and after the audits that permitted them to achieve and maintain food safety GAP certification. This undertaking involved observing and investigating the typical practices at the facility, deciphering the numerous and various 
requirements identified by the auditing organization, and, translating these requirements into needed changes through the development of a food safety plan.

\section{References}

Becker, B., Dawson, P., Devine, K., Hannum, C., Hill, S., Leydens, J., Palmquist, M. (n.d.). Case studies. Retrieved from http://writing.colostate.edu/guides/guide.cfm?guideid=60

Food and Drug Administration. (2018). Hazard Analysis Critical Control Point (HACCP). Retrieved from https://www.fda.gov/Food/GuidanceRegulation/HACCP/default.htm

Kline, T. R., Kneen, H., Barrett, E., Kleinschmidt, A., \& Doohan, D. (2012). Adapting Extension food safety programming for vegetable growers to accommodate differences in ethnicity, farming scale, and other individual factors. Journal of Extension, 50(1) Article 1IAW1. Available at: http://www.joe.org/joe/2012february/iw1.php

Mathiasen, L., Morley, K., Chapman, B., \& Powell, D. (2012). Using a training video to improve agricultural workers' knowledge of on-farm food safety. Journal of Extension, 50(1) Article 1FEA6. Available at: http://www.joe.org/joe/2012february/a6.php

Nayak, R., Tobin, D., Thomson, J., Radhakrishna, R., \& LaBorde, L. (2015). Evaluation of on-farm food safety programming in Pennsylvania: Implications for Extension. Journal of Extension, 53(1) Article 1FEA9. Available at: http://www.joe.org/joe/2015february/a9.php

Shaw, A., Strohbehn, C., Naeve, L., Domoto, P., \& Wilson, L. (2015). Knowledge gained from good agricultural practices courses for Iowa growers. Journal of Extension, 53(5) Article 5RIB3. Available at: http://www.joe.org/joe/2015october/rb3.php

Tobin, D., Thomson, J., LaBorde, L., \& Bagdonis, J. (2011). Developing GAP training for growers: Perspectives from Pennsylvania supermarkets. Journal of Extension, 49(5) Article 5RIB7. Available at: http://www.joe.org/joe/2011october/rb7.php

United Fresh Produce Association. (2015). GAP harmonization initiative. Retrieved from http://www.unitedfresh.org/food-safety/gap-harmonization-initiative

U.S. Department of Agriculture, Agricultural Marketing Service. (2015). Good agricultural practices (GAP) \& good handling practices (GHP). Retrieved from http://www.ams.usda.gov/services/auditing/gap-ghp

USDA, AMS, FVP, Specialty Crops Inspection Division (SCID). (2013). Produce GAPs Harmonized Food Safety Standard Post-harvest Operations - USDA Checklist, Version 2.0. November 1.

United States Department of Agriculture, Food Safety Inspection Service (FSIS). (2016). Inspection Methods Training - HACCP Seven Principles. March 15. Retrieved from https://www.fsis.usda.gov/wps/wcm/connect/9bef6a34-d7ef-441e-8478f431aee441cf/16_IM_HACCP_Principles.pdf?MOD=AJPERES

Vaughan, B., Zeigler, A., Wall, G. D., Robinson, M. D., Hodge, W. A., Bonsi, C. O., \& Hill, W. A. (2014). Case study of a food safety/good agricultural practices (GAPs) educational program for small and limited resource produce farmers. Professional Agricultural Workers Journal, 1(2), 1-7. Retrieved from http://tuspubs.tuskegee.edu/pawj/vol1/issue2/7 